\title{
TEKNIK NESNEDEN ESTETIK NESNEYE: ŞAKIR GÖKÇEBAĞ
}

\section{FROM TECHNICAL OBJECT TO AESTHETIC OBJECT: ŞAKIR GÖKÇEBAĞ}

\section{Öz}

\author{
Derya Baran *
}

Birçok akım ve teknikten beslenen Şakir Gökçebağ üç boyutlu çalışmalarında endüstri ürünü nesne/teknik nesne kullanır. Yerleştirmelerinde nesne-mekân birlikteliği ve mükemmeliyetçi yaklaşımı hep göz önündedir. Eserlerinde metamorfoz ile dönüşen teknik nesne ona bakan gözde görsel bir ahenk yaratır. Çoğunlukla kesme işlemiyle nesnenin biçimine müdahalede bulunur. Böyle bir müdahaleyle tanınırlı̆ı̆ı kaybetmeyen ama işlevi önemli ölçüde değiştirilen nesnenin bir daha önceki bağlamına dönmesi oldukça zordur.

Hazır nesne teknik nesnenin sanatçı tarafından seçilmiş ve sanat nesnesi olarak atanmış halidir. Yani endüstri ürünü nesnenin sanatta sahip olduğu statünün adı hazır nesnedir. Dolayısıyla önceki kimliğine ek olarak sanat alanında ikinci bir kimlik daha kazanan teknik nesne sanatta transpozisyon ile hazır nesneye dönüşür.

Makalede amaç hazır nesnenin sanatta bir statünün adı olduğundan dolayı malzeme olarak kullanılan her endüstri ürünü nesnenin hazır nesne olarak adlandırılamayacağı, bir başka deyişle hazır nesne kavramının sanatta kullanılan bir malzeme adı olmadığı belirlemeleri üzerinden teknik nesnenin estetik nesneye dönüşümünü ele almaktır. Bu nedenle Şakir Gökçebağ'ın teknik nesne kullanımına bu bağlamda dikkat edilmiş, sanatçı ile ilgili literatür araştırması yapılarak eserleri incelenmiştir.

Anahtar Kelimeler: Şakir Gökçebağ, Teknik Nesne, Estetik Nesne, Hazır Nesne, Marcel Duchamp.

\begin{abstract}
Şakir Gökçebağ, who is fed by many movements and techniques, uses industrial products/technical object in his three-dimensional works, and object, space coexistence and perfectionist approach are always in mind. The technical object transformed by metamorphosis in his works creates a visual harmony in the eye that looks at it. He often interferes in the shape of the object by cutting. It is quite difficult for the object to return to its previous context, for by such intervention the object has not lost its ow identifiability, but its function has been significantly altered,

The readymade is the technical object selected by the artist and assigned as an object of art. In other words, the name of the status of the industrial object in the art is the readymade. Therefore, in addition to its previous identity, the technical object that gains a second identity in the field of art is transformed into readymade by transposition.

The aim of the article is to discuss the transformation of technical object into aesthetic object by determining that readymade is not the name of a material used in art because it is the name of a status in art and every industrial product used as a material in art cannot be called as readymade. For this reason, attention was paid to the use of technical objects of Şakir Gökçebağ in this context, and the literature is searched about the artist and his works are examined.
\end{abstract}

Keywords: Şakir Gökçebağ, Technical Object, Aesthetic Object, Readymade, Marcel Duchamp.

Araştırma Makalesi // Başvuru Tarihi: 05.08.2019 - Kabul Tarihi: 31.12.2019

*Dr. Öğr. Üyesi, Van Yüzüncü Yıl Üniversitesi, Güzel Sanatlar Fakültesi, Heykel Bölümü, deryabaran@gmail.com, https://orcid.org/0000-0002-5827-9468. 


\section{Giriş}

Nesne insan evriminin her evresinde ister doğal ister üretilmiş olsun yaşam, üretim ve kültür alanlarının oluşturulmasında, bu alanların geliştirilmesinde önemli rol üstlenir. Maddi bir varlık olarak doğada bulunan nesneler doğal nesne ve yapay nesne olarak ikiye ayrılır. Doğal nesne kategorisini insan katkısı olmadan doğada bulunan her türlü nesne oluşturur. Yapay nesne kategorisi ise teknik nesne (endüstri ürünü nesne) ve estetik nesneden (sanat eseri) oluşur. İnsan aklı ve beceri yeteneği ile meydana getirdiği bu yapay nesnelere maddi ve manevi anlamlar yükler. İmge, madde ve biçimi dönüştürme edimine sahip sanatçının da bünyesinde anlamlar hapseden ve bir değeri olan nesneden etkilenmemesi pek mümkün değildir. Bu anlamda bir dürtü ile nesne ilk kez Kübistler tarafından kullanılır. Teknoloji ise önüne geçilemez biçimde nesne çeşitliliğini arttırmaya devam eder. Teknik ilerlemenin yarattığı bu hız karşısında sanatçı çeşitli sanatsal teknik ve yaklaşımlarla yeni olanakları aramaya, denemeye çalışarak bu çeşitliliğe sanat alanından sorular üretir. Bu soruların ilk ve en keskin örneği Marcel Duchamp’a aittir. Duchamp endüstri ürünü bir nesneyi sahiplenerek sanat alanına taşımıştır. Böyle bir nesnenin dönüşümü ilkin zihinde belirir. Buna bağlı olarak sanatı zihinle okumak ona bakan herkesin üreteceği yeni anlam ve yorumlar ortaya çıkarır.

1965 Denizli doğumlu Şakir Gökçebağ Lisans eğitimini Marmara Üniversitesi Güzel Sanatlar Fakültesi Grafik Bölümü’nde tamamlar. Aynı üniversitenin Sosyal Bilimler Enstitüsü’nde Yüksek Lisans eğitimini 1990, Sanatta Yeterlik Eğitimini ise 1994 yılında alan sanatçı çeşitli burslar ile eğitimine yurtdışında da devam etmiştir. 2001 yılından itibaren Hamburg'da yaşamakta ve çalışmaktadır. 1996'da Markus Lupertz Ödülü, 2012'de George Maciunas Ödülü ve 2016 'da Leo Breuer Ödülü bulunan sanatçı başta Almanya ve Türkiye olmak üzere dünyanın çeşitli yerlerinde çok sayıda sergi açmıştır. Kariyerinde bir akımın temsilcisi olma durumundan çok sanattaki pek çok yaklaşımdan etkilenir ve farklı teknikleri kullanır. Ayrıca işlerinde bir doğubatı sentezi de mevcuttur (Şakir Gökçebağ Portfolyo Serisi 1, 2013:5). Türkiye ve sonrasında Almanya'da yaşaması bu iki kültür ile hemhal olan işlerini ortaya çıkarmıştır. Sanatçı resim, baskı resim, fotoğraf üretimlerinin yanı sıra endüstri ürünü nesne kullanımı ve mekâna yönelik araştırmalardan oluşan geniş bir üretim yelpazesine sahiptir. 
Şakir Gökçebağ üç boyutlu üretimlerinde elle yapmak yerine teknik nesneyi kullanır. Gökçebağ’ın teknik nesne içeren sanat üretimini yalnızca belirli bir türe özgü bir yaklaşımla kategorileştirmek pek mümkün görünmez. Bunun nedeni sanatçının birçok akım ve teknikten beslenmesidir. Şakir Gökçebağ’ın teknik nesne kullanımının sanatçıyla ilgili bazı kaynaklarda "hazır nesne", "ready-made" ve "ready-made vari" üretimler olarak bahis bulduğu görülmektedir. Bu noktadan hareketle çalışmada amaç sanat eserinde malzeme olarak kullanılan her teknik nesneden/endüstri ürünü nesneden ötürü o sanat eserinin statüsünün bir hazır nesne olmadığı/olamayacağı durumundan hareketle teknik nesnenin sanattaki dönüşümünü tartışmaktır. Zira hazır nesne kullanılan bir malzemenin ismi ya da bir teknik nesnenin, bir endüstri ürününün (yapılmış, hazır, üretilmiş nesne anlamında) karşılığı değildir. Hazır nesne sanatta bir sonucun, bir statünün adıdır. Bu olmama/olamama durumu Duchamp'ın hazır nesne tekniği üzerinden ele alınmak zorundadır. Dolayısıyla Şakir Gökçebağ’ın teknik nesnelerden ürettiği eserleri bu minvalde çözümlenmeye çalışllacaktır.

\section{Teknik Nesne, Estetik Nesne, Hazır Nesne}

Ağırlığı ve hacmi olan her cansız varlık bir nesnedir. Tesadüf ve deneyimle her yeni döneme göre değişen malzeme ve nesnelerden maddi bir dünya yaratır, bunlarla içli dışlı şekilde yaşar, üretir ve tüketiriz. "Nesnelerle ilişkimiz mesafeli değildir, her nesne vücudumuza ve yaşamımıza seslenir, insan özelliklerine bürünür (uysal olur, tatlı olur, bize karşı koyar...); tersi de geçerlidir, bu nesneler sevdiğimiz ya da nefret ettiğimiz davranışların simgeleri gibi yaşarlar içimizde. İnsan şeylere yatırım yapar, şeyler insana" (Merleau-Ponty, 2005:31). İcat etme, kullanma, değiştirme, geliştirme ve yeniden üretme ile oluşturduğumuz bu içli dışlılık nesneleri algılama biçimimizi de değiştirir. İnsanın işlevsel kullanımı dışında nesneye anlam yüklemesi biriktirme, saklama, muhafaza, bellek yaratma ve koleksiyon oluşturma gibi nedenlerle mütemadiyen eksikliğini hissettiği bir boşluğu doldurmak ve maddeye sıkışmış olanı bulup çıkarmak şeklinde yorumlanabilir. Rönesans'ın Nadire Kabinelerinden sanatçının atölyesine kadar gelen sürecinde nesneyi, değişik düzen ve ilişkiler sisteminde kolaj, montaj, asamblaj, buluntu nesne, hazır nesne ve çoğaltma gibi tekniklerle manipülasyona uğratan sanatçı zihni de onu yeni okumalara maruz bırakmıştır. 


\section{SDÜ ART-E}

Güzel Sanatlar Fakültesi Sanat Dergisi

İnsan tarafından oluşturulan her varlık üretilmiş, yapay bir nesnedir. Yapay nesnenin yapısında bir dualite vardır; somut bir varlıktır fakat gerçek doğa değildir. Yapay nesneleri kendi içinde ikiye ayırmak mümkündür: "teknik nesne (endüstri ürünü nesne)" ve "estetik nesne (sanat eseri)”. Her biri bir tasarım varlığı olan her iki nesne türü özünde birbirinden farklıdır. Teknik nesnede işlevsel olma özelliği ön plandadır. Tasarlanmış seri üretim ürünüdürler dolayısıyla tinsel değillerdir. Onu tasarlayan hakkında öznel hiçbir ipucu göstermezler. Genel beğeniye hitap etmek zorundadırlar, bu nedenle de estetik bir norm kazanırlar. Teknik bir nesne de estetiktir fakat bu onun olması gereken ilk özelliği değildir. Sanat eserinin ise güzel, estetik bir nesne olması doğası gereğidir. Sanatçı edimi sonucu ortaya çıkan estetik nesne tektir, bir defaya mahsus üretilmiştir. Özgün ve özgürdür. Tinseldir, duygularımıza hitap eder. Ayrıca estetik nesne maddeselliği dışında izleyenin estetik algısıyla sanat eserine dönüşür. "Estetik deneyimde görünüşe çıktığı şekliyle sanat eseri, ne salt bir real nesnedir (yani yalnızca şeyvarlığından ibarettir) ne de salt bir ideal nesnedir (yani bilincin kurduğu öznel bir tasarımdır); fakat fenomenal varoluşa sahip duyusal bir nesnedir" (Altuğ, 2012:217). Ama yine de hem teknik hem estetik nesneyi ona duygularımızı aktararak veya kendimizi başka bir tasarım varlığının içinde duyarak yani çoğunlukla özdeşleyim yoluyla kavrarız. Nesneyle kurulan böylesine kişisel ilgiler onu değerli kılar ve estetikleştirir. Bu aynı zamanda teknik nesneyle de bütünleşmeye götüren yoldur.

Sanatta kullanılan her malzeme bir dönüşüm yaşar: kil, ağaç, taş, metal vs. gibi malzemeler biçim değişimiyle sanat formuna dönüşür. Yani birçok alanda olduğu gibi sanat alanında da dönüşüm/dönüştürme anlamında kullanılan bir terim olan metamorfoz ya da transformasyon ile. Teknik nesneyi yani endüstri ürünü nesneyi hazır nesneye dönüştüren ise transpozisyondur. Yapısında dikkate değer bir değiştirme yapılmadan yerini/bağlamını değiştirmek suretiyle ve de öncelikle sanatçısı tarafından zihinde yapılan bir yer değiştirme ile teknik bir nesne hazır nesneye dönüşür. Teknik nesne hazır nesne tekniğinden sonra geri döndürülemez şekilde sanata dâhil edilmiştir. "Artık tüm insan yaşantısını sanat eserine dönüştürebilecek olanaklara sahip olduğumuzun farkındayız" (Baudrillard, 2005:106). Bu farkındalığı sanat kanonunu sarsmak amacıyla hazır nesneyi öneren Duchamp yaratmıştır. 
"Bicycle Wheel (Bisiklet Tekeri/1913)" ile başlayan bu yaklaşım sonraki zamanlarda sanat tarihinde kanon olmaktan kurtulamamıştır (Görsel 1).

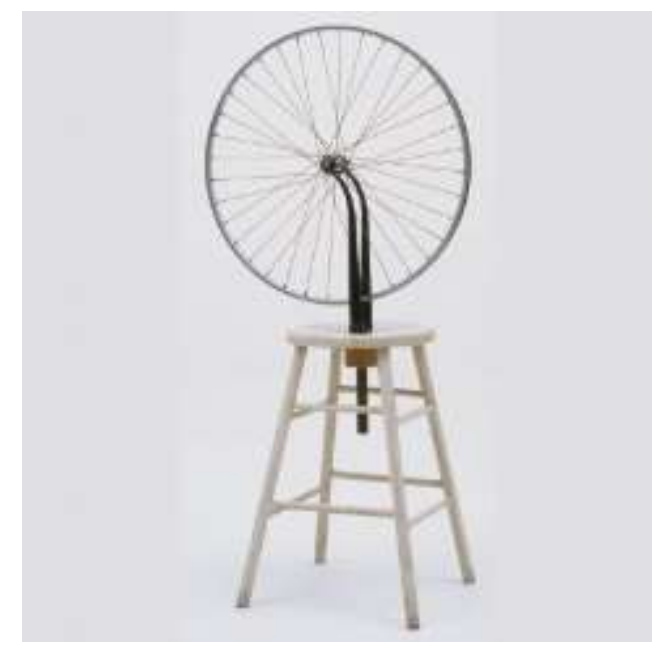

Görsel 1. Marcel Duchamp, Bicycle Wheel (Bisiklet Tekeri), 1913/1951, Hazır Nesne, 129.5x63.5x41.9 cm., MOMA.

Ancak sanatta malzeme olarak kullanılan her gündelik nesne bir hazır nesne olarak sanat nesnesine dönüşmez. Hazır nesne bundan başka bir şeydir. Sanatçı tarafından seçilerek temsil edilen ve yapısında dikkate değer bir değiştirme yapılmamış teknik nesnenin sanatta kazandığı statünün adıdır hazır nesne. Teknik nesne sanatçısı tarafından seçimi, yeniden adlandırması, imzalaması, iş̧levini değiştirmesi, yeni bir bağlamda sunması ve fotoğraf vs. ile kayıt altına alması ile haklı bir dönüşüm geçirerek hazır nesne statüsü kazanır. Bu nesneler önceki kimliklerini yeni kimlikleriyle birlikte korudukları için çift kimliklidirler. Hazır nesne güzel, çekici, hoşa giden ya da tam tersi itici olmamalı, sanatçısının seçiminden izleyicinin bakışına tam bir tarafsızlıkla ulaşmalıdır. Defalarca yinelenen bir eylemin alışkanlığa, beğeni ve zevke götüreceği çok açıktır. Bu nedenle Duchamp estetik algıdan kurtulmak ve teknik nesnenin bu dönüşümünde beceriksizlik, kolaylık ya da pasiflik olarak yorumlanabilecek durumları saf dışı etmek için (çünkü hazır nesne geleneksel üretim yöntemleri ile açıklanamaz) hazır nesne üretimlerini sınırlı sayıda tutmuştur.

Herhangi bir nesnenin bütünden uzaklaştırılmış bir veya birkaç parçasının beğeni faktörü ile sanat nesnesine dönüşmesi olarak tanımlanabilecek buluntu nesne de hazır nesneden farklıdır (Görsel 2). Çünkü buluntu nesne hazır nesne gibi estetik beğeniden 
koparılarak kullanılmamıştır. Sanat tarihinde en önemli buluntu nesne örneği Picasso'nun “Boğa Başı"dır. Picasso bisiklet gidonu ve selesine rastladığında onları zihninde bir boğa başı olarak dönüştürmüştür. İlk kimliklerini koruyan malzemelere işlevsel bir değişiklikte bulunulmamış, bağlam değiştiren nesneler yeni bir kimlikle bir imgeye dönüşmüşlerdir.

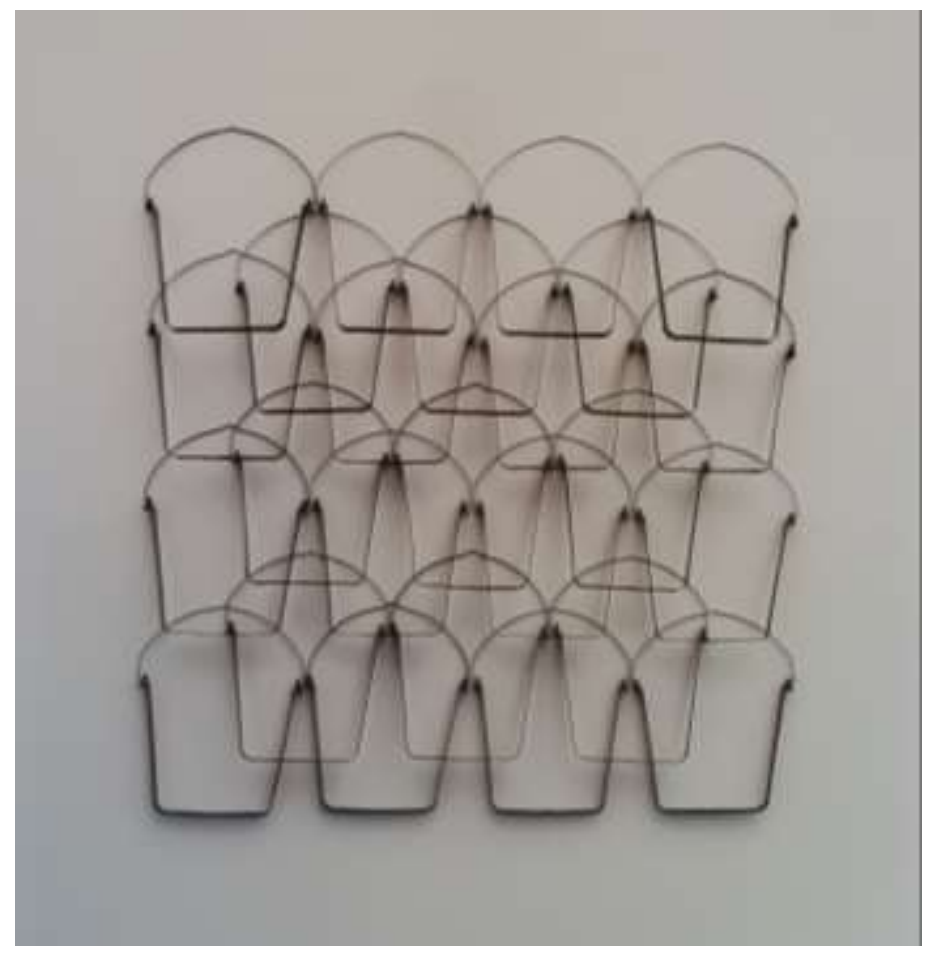

Görsel 2. Şakir Gökçebağ, Minifesto, 2016, Plastik Kovalar, 165×128x5 cm.

Duchamp'ın aura ve tekil nesnenin kutsiyetini yıkmak amaçlı bilinçli tercihi ile teknik nesneyi sanat alanına sunması sanat üretim tekniklerini ve sanat algısını değiştirmiştir. Sanatçı artık el ile üreten değil, var olanlar arasından seçen, onu yeni bir kimlikle öneren ve kendine mal eden olmuştur. Estetik beğeniye hitap eden sanat üretimine karşı çıkarak akla hitap edeni üretmekti onun isteği. Geleneksel temsilden kurtularak sanatın akla sunulduğu bu yönlü bir sanat anlayışı disiplinler arası sanatı birbirine yakınlaştırdığı gibi sanat eserine bakışta da izleyiciye yeni okumalar yaratmıştır. Aslına bakııırsa bu ilgiyi yaratmada Duchamp yalnız değildi. I. Dünya Savaşı'nın ortaya çıkardığı dehşet inanç politikalarını yerle bir edince Dada ile başlayan protesto ruhu sanatçıları sanatta güzelin araştırılmasından vazgeçirdi. Marcel Duchamp'ın hazır nesnesi ve kavramsal sanatla başlayan dönüşümden sonra geleneksel form üretme kaygıları 
seyrelmiş, yapıtın nasıl üretildiğinden çok niçin üretildiği yani barındırdığı düşünce önem kazanmıştır.

Gökçebağ'ın sanatında teknik nesneyi kullanması ile ilgili olarak, kendi beyanı olmamakla birlikte, yayımlanmış bazı kitap, sergi kataloğu, basın bülteni ile internet sayfalarında "ready-made vari"1, "ready-made"2 ya da "hazır nesne"3 üretimler olarak sınıflandırılmış ya da bağlantı kurulmuş olduğu görülmektedir. Bir sanatçı tarafından transpozisyon ile hazır nesne statüsünü kazanan teknik nesne artık sanat dünyasında ya hazır nesnedir ya da değildir. Hazır nesne ikilemli tanımlamalara da maruz bırakılmamalıdır. Çünkü zaten keskin bir ayrımdır sanat tarihinde. Bu nedenle kesin tanımlamalarla açıklanmalıdır. Bu kesinlik ise hazır nesne tekniğini tam bir tarafsızlıkla sanat dünyasına öneren Marcel Duchamp izleğinden çözümlenmek zorundadır. Duchamp'ın hazır nesnesi nötrdür, estetik kaygıdan uzaktır (Görsel 3).

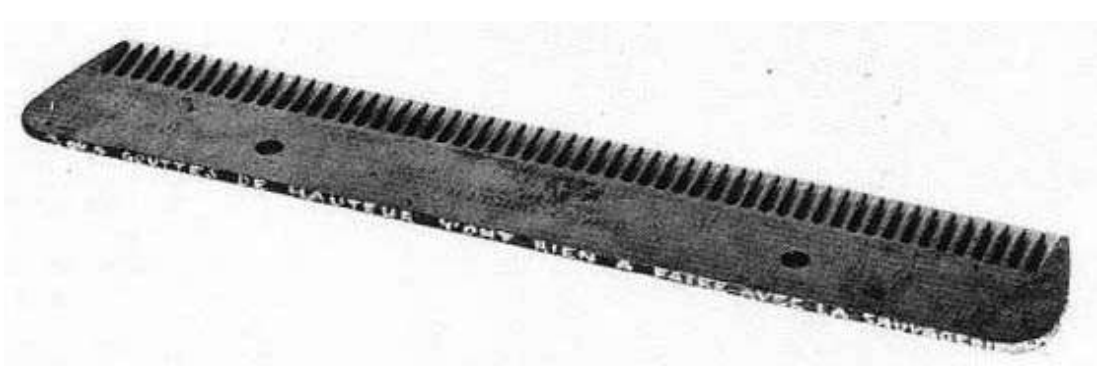

Görsel 3. Marcel Duchamp, Comb (Tarak), 1916, Hazır Nesne, $16.6 \times 3 \times 0.3 \mathrm{~cm}$, Philadelphia Sanat Müzesi, Louise ve Walter Arensberg Koleksiyonu

\section{3. Şakir Gökçebağ’ın Estetik Nesne Üretimi}

\footnotetext{
1 “ready-made vari”, bkz. Marcus Graf, (2011). "Şakir Gökçebağ”, Her Yerde Evinde, ed. Mine Haydaroğlu, İstanbul: Yapı Kredi Yayınları, s.27.

2 “ready-made”, bkz. Marcus Graf, (2011). "Şakir Gökçebağ”, Her Yerde Evinde, ed. Mine Haydaroğlu, İstanbul: Yapı Kredi Yayınları, s.37, Marcus Graf (2013:1). "Şakir Gökçebağ Portfolyo Serisi 1", http://platosanat.org.tr/Uploads /Document/c6575d4e-e019-4123-a96c-6f0c68a991e5.pdf?v-636421616092235780, Erişim tarihi: 26.02.2019; Müjde Metin, (2015), “Şakir Gökçebağ'ın Evrensel Objeleri", Think Thank, Galerist, http://www.galerist.com.tr/wpcontent/uploads/downloads/2015/03/SAKIR_GOKCEBAG5.pdf, Erişim tarihi: 03.04.2019.

3 “hazır nesne”, bkz. "Şakir Gökçebağ 'Think Thank', http://www.galerist.com.tr/wp-content/uploads/downloads/ 2015/02/SAKIR-GOCEBAG_THINK-TANK_BB2.pdf, Erişim tarihi: 03.04.2019; “Önüm Arkam Sağım Solum”, Şakir Gökçebağ, ADAS, (11 Eylül - 21Ekim 2017)”, http://kolajart.com/wp/2017/09/08/onum-arkam-sagim-solum-sakirgokcebag-adas-11-eylul-21ekim-2017/, Erişim tarihi: 26.02.2019.
} 
Şakir Gökçebağ sıradan objeler kullanır (Görsel 4). Bu yolla üretimlerinin anlaşılır olması tercihi kullandığı nesnelerin seçim mantığını da gösterir. Bilinen nesneler beklenmedik halleriyle izleyici karşısına çıkarken yaratılan görsel farklılık zihinde yeni bir algılama düzeneği oluşturur. Sanatçı en sıradana bakışımızda bile sıradan olmayan bir şeyleri bulup çıkararak bir nesneye, bir kavrama, bir olgu ya da bir duruma karşı sonsuz olasılıklarla bakma ve anlama hacmimizi genişletir. Her an her yerde rastlanılabilir nesneler onun için bir deney alanı yaratır, aynı nesne değişik süreçler geçirerek farklı farklı işlere evrilir. Kullandığı materyalin ne olduğu ya da biçiminden çok o materyali dönüştürme süreci Gökçebağ için daha belirleyicidir. "Eline düşen her şeyi mercek altına alır ve bir araştırmacı gibi her nesnenin estetik potansiyelini inceler." (Auer, 2017:5). Marcel Duchamp hazır nesnelerinde beğenin kesin yargısından kurtulmak için nesneyle karşılaşma sürecinin de anlık olması gerektiğini söylemiştir. Ancak Şakir Gökçebağ bu sıradan tasarım nesnelerin dönüştürülmesi esnasında onlara özel önem verir. Algılama ve keşfetme yoluyla form zenginliğini ve mevcut alternatif kullanım olanaklarını vurgulamak için sıradan bir dünyaya dalma riskini göze alır (Schönfelder, 2017:13). Sanatçı genel olarak günlük yaşamda aklına gelen fikirleri not alarak ve bunların uygulamasını daha planlı bir anda yaparak eser üretir.

... Biriken fikirler büyük bir repertuar oluşturur bende. Bir sergi söz konusu olduğunda o mekana özgü projeler üretmek isterim. Mekanı görmem, olamıyorsa fotoğraflarını görmem lazım. Yaratım aşamasında arşivimdeki fikirlerden yararlanırım. Bu çizimler sergi aşamasına gelene kadar 5-10 yıl orada beklerler. Sergi öncesi son ana kadar değişiklik yapma ihtimalim hep vardır. (Topal, 2017).

Çalışma şeklini şöyle açıklamaktadır:

Bir sanat eseri üretmem için genelde bir başlangıç noktasına intiyacım var. Bu bir obje de olur, bir mekân da. Sonuçta o objeye ya da mekâna bir şeyler ekleyip çıkartıı.ı. Pek çok projeyi bir arada tasarlarım. Birini bitirmeden ötekine geçebilirim. Zaman içinde periyodik olarak bu çalışmalarıma göz atar, onlara ekleme ve çıkarmalar yaparım. Sanatın her yerde olabileceğine inandığım için, her mekân/görüntü veya etrafımdaki her şey ilgi alanıma girer. (Şakir Gökçebağ Portfolyo Serisi 1, 2013:6). 


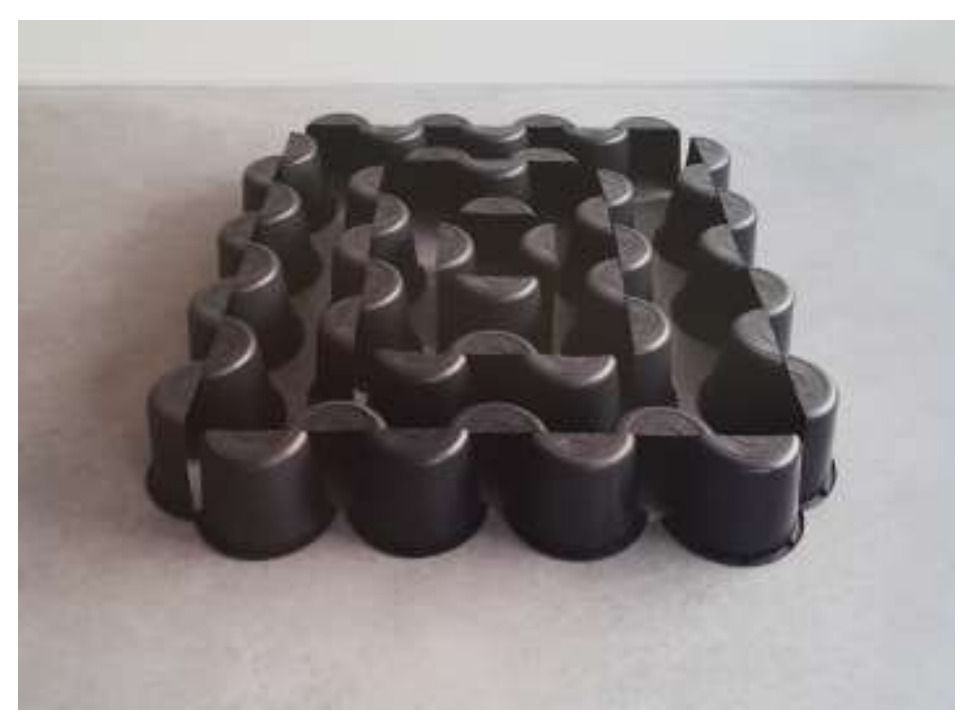

Görsel 4. Şakir Gökçebağ, Ohne Titel (Isimsiz), 2017, Plastik Kovalar, 26×180×165 cm.

Günlük kullanım nesnesiyle sanatsal üretimde bulunmanın zorlukları da mevcuttur, Şakir Gökçebağ bunun altını çizer:

Malzemeleri bulmak, saklamak benim için çok önemli bir sorun. Birer ikişer tane bulmak ve onlarla deneysel şeyler yapmak kolay. Ama bir sergi söz konusu olduğunda, aynı objeden çok miktarda gerektiğinde problem oluyor. Sonra bunların saklanması da ayrıca bir sorun: Büyük mekân gerektiren objeleri saklama imkânım olmadığı için imha ettiğim çok olmuştur. Tekrar sergileme söz konusu olursa yeniden satın alıp yapmak gerekiyor. Aradığımın aynısını bulamadığım, artık üretilmeyen çok şey var (Şakir Gökçebağ Portfolyo Serisi 1, 2013:9).

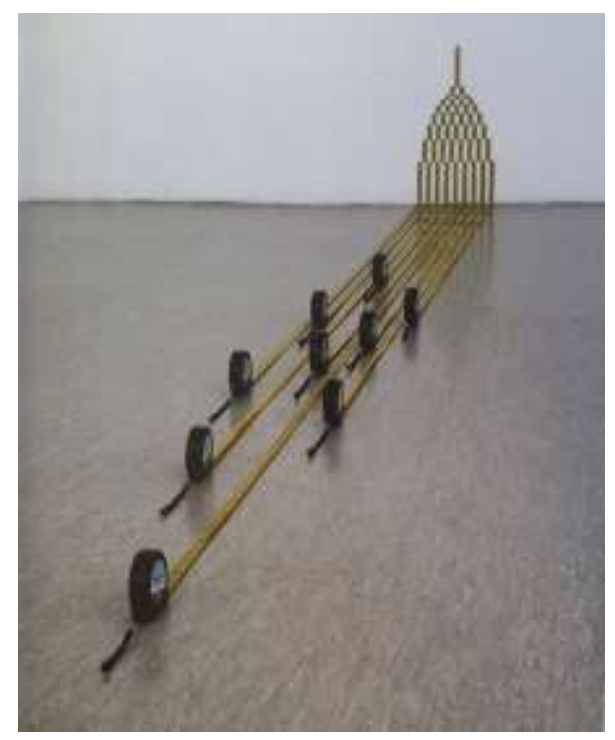

Görsel 5. Şakir Gökçebağ, Skyscraper \# 3 (Gökdelen \# 3), 2011, Şerit Metreler, Çeşitli Boyutlar. 
Heykelden ayrı, bulunduğu mekânla doğrudan iletişime geçen veya o mekan için özel üretilen adına Yerleştirme (enstalasyon) dediğimiz melez türde de nesne kullanılmıştır. "Burada yapıt, ne tek başına sergilenen malzeme ne de mekân değil, bütün olarak yapıtın, mekânın işlevi, anlamı, belki de tarihi ile ilişkiye girdiği algı boyutudur. Anlatım dili olarak nesne yerleştirmesini seçen sanatçı, mekânı ve nesneleri araç olarak kullanarak düşünsel, estetik ve kavramsal düzlemlerde bir olguyu irdelemektedir" (Özayten, 1997:1939-1940). Şakir Gökçebağ seçtiği nesneleri mekân kavramıyla kurgular ya da mekânı seçtiği nesnelerle tamamlar. Hâlihazırda verili bir mekânı sıradanlıktan kurtararak hareketlendirir. Kompozisyonlarında simetri kullanır ve onları daire, dikdörtgen, kare gibi geometrik şekillerde düzenler (Schönfelder, 2017:13). Buna örnek olarak verilebilecek "Three Basic Prayers (Üç Temel Dua)/2010" isimli enstalasyonunda kullandığı nesnenin tanınırlığına hiçbir müdahalede bulunmadan temel geometrik formlarda duvar yüzeyinde yan yana sıralamış olduğu görülür (Görsel 6).

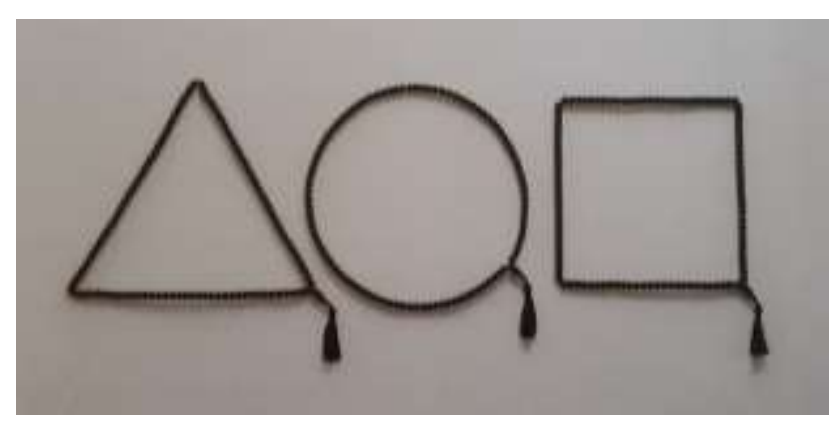

Görsel 6. Şakir Gökçebağ, Three Basic Prayers (Üç Temel Dua), 2010, 102x42×1cm.

Sanatçısının anlık seçimle bağlam değiştirerek sunduğu hazır nesneden farklı olarak sanatta obje kullanımında varyasyon üretmek aradığını bulmakta önemli bir yol olabilir. Teknik nesnenin genel beğeni ile kazandığı estetik normdan kaynaklı tanımlanmış belirlenmişlikleri mevcuttur. Yani böyle bir nesne sağlam, işlevsel, ergonomik, biçimsel olarak çarpıcı vs. olma gibi net kurallara göre üretilir. Bu nedenle nesne üzerinde manipülasyon olanakları birden fazla yol denemeye götürebilir sanatçıyı. Yeni yollar, yeni fikirler, yeni bir bakış üretmek için bu deneme-yanılma süreci sanatsal üretim açısından oldukça besleyicidir. Sanatçı birçok materyali farklı varyasyonlar ile estetik nesne olarak önermektedir. Nesnenin doğasına aykırı arayışları 
kendine temel alan Şakir Gökçebağ malzemenin bu anlamdaki sınırıılı̆ını çeşitlemeler üreterek aşar.

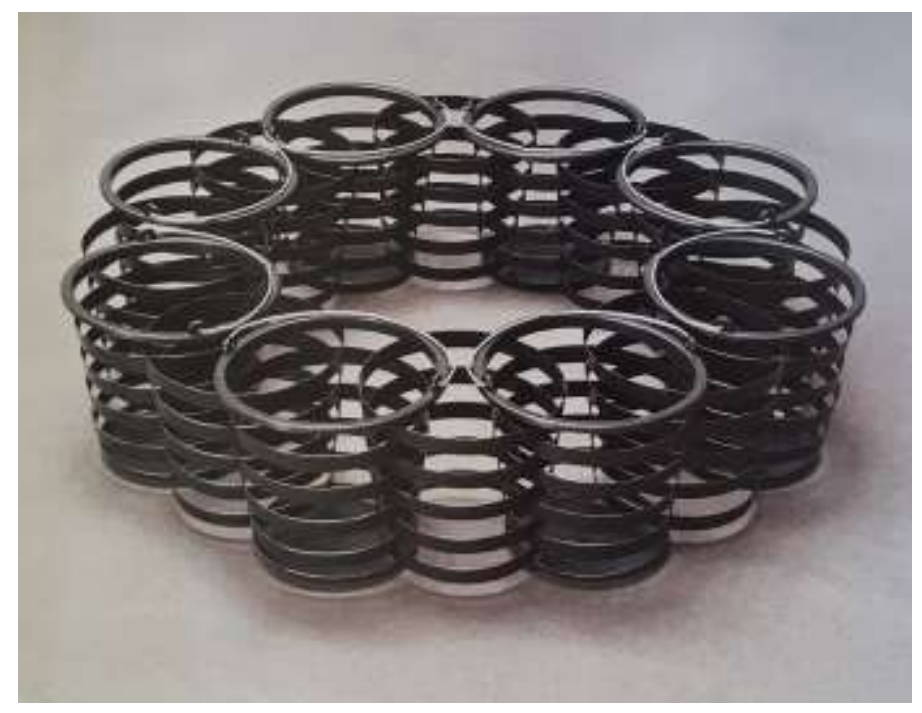

Görsel 7. Şakir Gökçebağ, KV1 18, 2016, Plastik Kovalar, 27x117x117 cm.

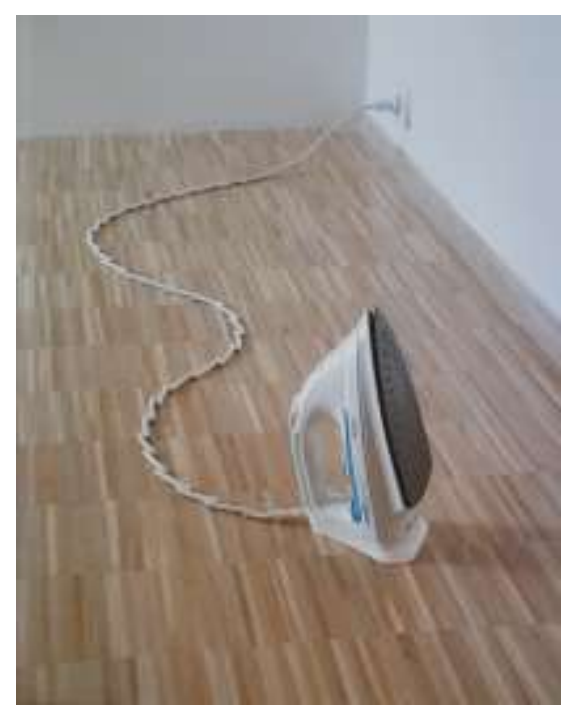

Görsel 8. Şakir Gökçebağ, Ohne Titel (İsimsiz), 2008, Ütü, Çeşitli Boyutlar.

Yetiştiği kültürün alt metnini yine bu kültüre ait nesnelerle çakıştıran Gökçebağ göç, aidiyet, kimlik vs. gibi evrensel kavramları ele alır. Tarak, fırça, ayakkabı, lastik çizme, plastik hortum, şemsiye, mandal, tuvalet kâğıdı, elbise askısı, plastik kova, şerit metre, su terazisi, saat, kemer, kayış, gömlek, tespih, halı vs. gibi sıradan nesnelerle düzenlemeler, birleştirmeler ya da 


\section{SDÜ ART-E}

Güzel Sanatlar Fakültesi Sanat Dergisi

Aralık'19 Cilt:12 Sayı:24

ISSN 1308-2698

ayrımlar yaparak Minimalizm ve Kavramsal Sanatın azlık ilkesini benimsediğini gösterir. Sanatçının birleştirme, ayrıştırma ve tezatııkla kurduğu bu ilişkide titiz, takıntılı bir düzenlilik ile mesafeli ve mükemmeliyetçi yaklaşımı da göz önüne serilir. Bazen tek bazen de çoğaltma şeklinde kullandığı nesneler yine de bu azlık ilkesine ihanet etmez.

Özel düzenlemeleri ve dengeli kompozisyonları, nesnelerin başlangıç formlarını kapsamlı şekilde değiştiren imgeler yaratır. Yine de, teknikleri genel olarak şaşırtıcı derecede basittir. Şakir Gökçebağ, kısmen günlük deneyime olan yakınlığı korumak için kasıtlı olarak fiziksel müdahaleden veya teknik girdiden kaçınır. Çoğaltma, yansıtma ve sıralı yaklaşımlar gibi düşük teknolojili yöntemler bile öğelerin kendi başlarına yeni bir yaşam sürmeleri için yeterlidir. Tek tek nesnelerin kesilmesi, yeniden düzenleme, değiştirme ve alışkanlığı kırma işlemlerini kolaylaştırır. Sanatçı, duvardaki veya zemindeki nesneleri (veya bunların parçalarını) grafik ve kaligrafik öğelere, jestlere ve yerleştirmelere göre düzenler (Schönfelder, 2017:13).

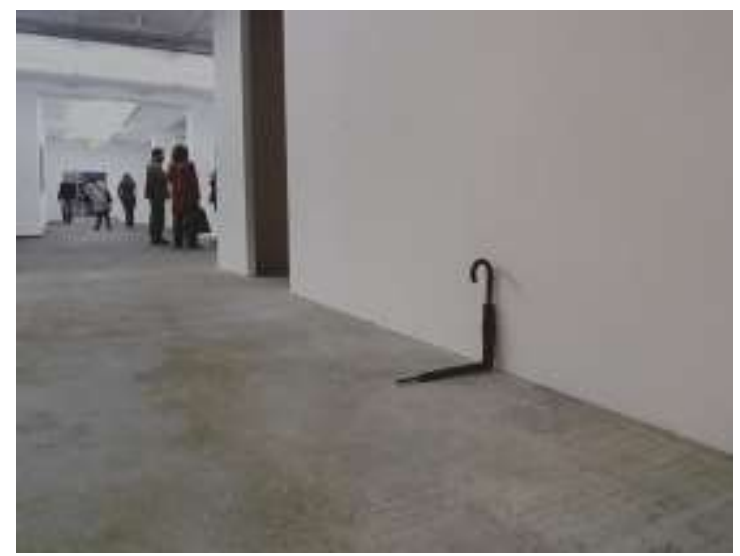

Görsel 9. Şakir Gökçebağ, Ohne Titel (İsimsiz), 2011, Şemsiye, 46×48×6 cm.

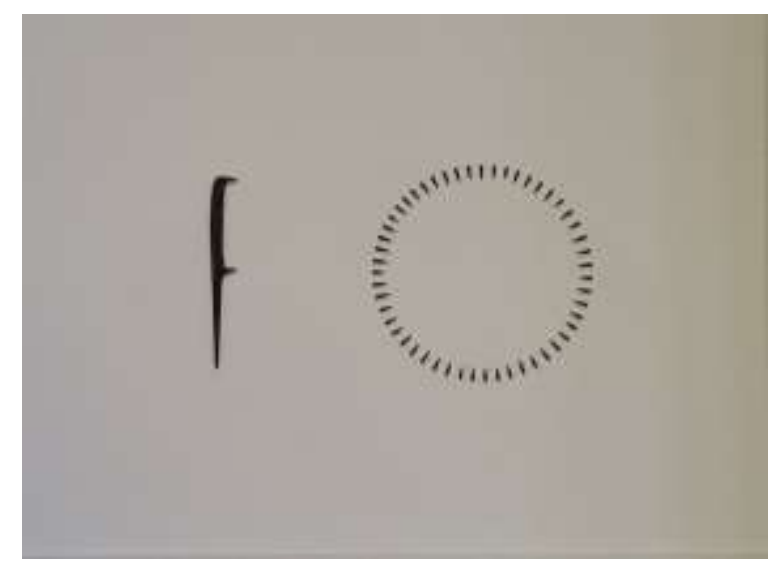

Görsel 10. Şakir Gökçebağ, TRK-4, 2011, Tarak, 60×80 cm., "Combosition” serisinden. 


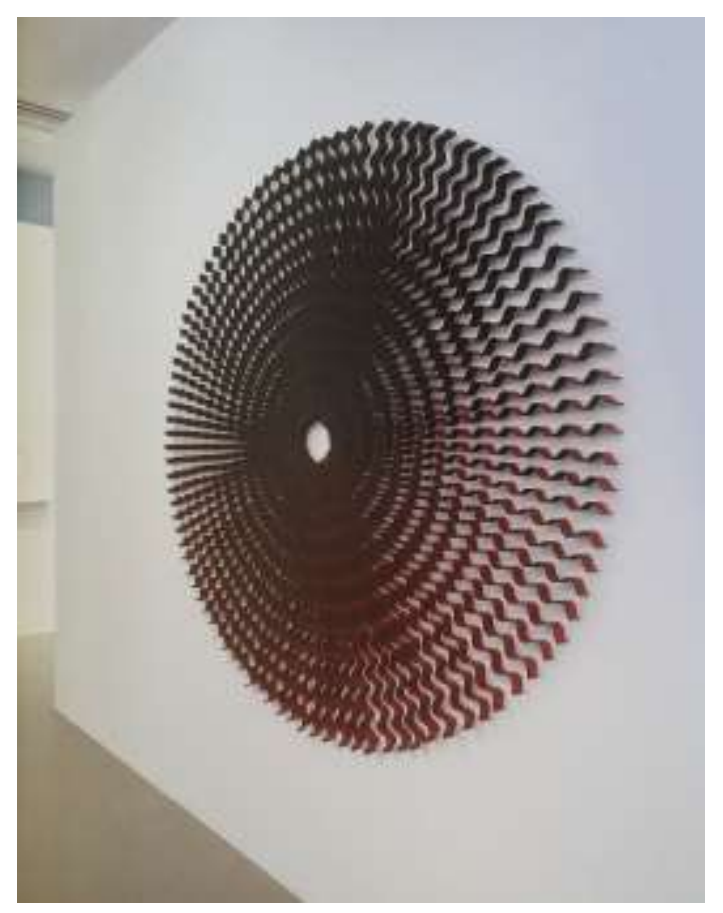

Görsel 11. Şakir Gökçebağ, Ohne Titel (ísimsiz), 2017, Oluklu Levha, Ø 205 cm.

Gökçebağ'ın mütevazı seçimlerinden oluşan eserleri sakin ve sessizce galeride izleyiciyle karşılaşmayı bekler. Sanatçı "şeyleri kahramanlaştırmakla ilgilenmez" (Glasmeier, 2013:6) ancak eserle karşılaşarak bu basit ve günlük materyallerdeki dönüşümü fark eden izleyicinin bunları kahramanlaştırmaktan ya da nesneyi yüceltmekten başka çaresi kalmamaktadır. Olduğu gibi, kesilmiş, eklenmiş ya da çoğaltılmış bu materyallerin birbirleriyle ve mekânla kurduğu ilişki bakanı da yeni bir gözle görmeye ve düşünmeye çağırır. Sanatçı-Eser-Alımlayıcı sıralamasında özellikle alımlayıcı ve eser ilişkisini önemsemekte, bu nedenle eser adlarının bir dayatma sunmasını istememektedir. Gökçebağ'ın nesne sanatı temelde çeşitliliğe dayalı bir kombinasyondur. Dada, Sürrealizm, Fluxus, Minimalizm, Pop Art, Arte Povera gibi akımlar ile buluntu nesne, asamblaj, montaj, çoğaltma, yerleştirme tekniklerinin birleşiminden beslenerek ortaya çıkan günlük nesnelerden ürettiği eserleri yeni okumalar açığa çıkarır. Dolayısıyla üretimlerini belirli bir türe özgü bir yaklaşımla ayrıştırmak pek mümkün görünmemektedir. Üretimleri bu akım ve tekniklerden hem benzerlikler taşır hem de farklılıklar.

...sanatçının nesneler kozmosu (düzeni, evreni), Sürrealizmin şey metamorfozlarından, Konstrüktivizmin renk ve forma dayalı şey eklemelerinden, Dadaist montaj prensibinden veya Pop Art ve Postmodernizmdeki metaların yüceltilmesi veya eleştirilmesinden farklıdır. Yine de 


\section{SDÜ ART-E}

Güzel Sanatlar Fakültesi Sanat Dergisi

Aralık'19 Cilt:12 Sayı:24

ISSN 1308-2698

bazı bakış açılarından, Şakir Gökçebağ'ın şeylerle ilişkisinde bu stratejik sanat tarihi yöntemlerini birleştirdiği söylenebilir (Glasmeier, 2013:6).

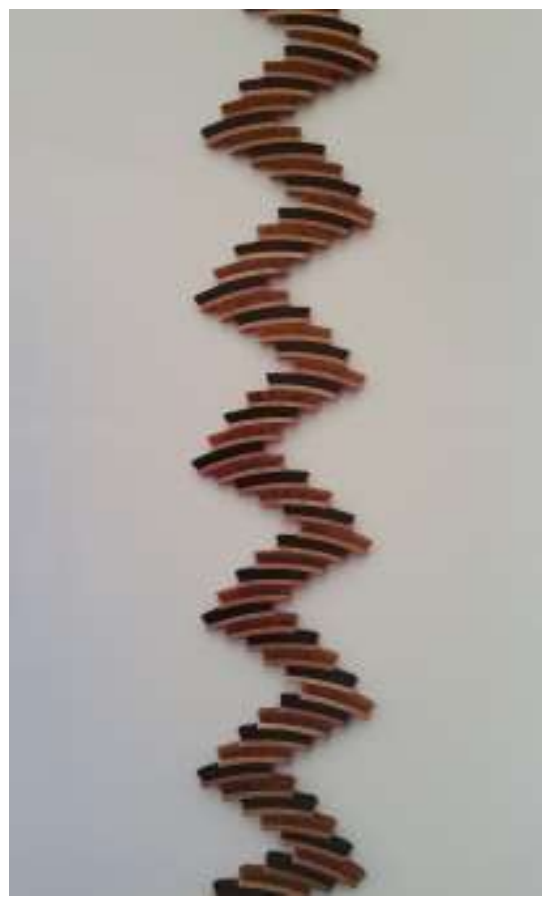

Görsel 12. Şakir Gökçebağ, Ohne Titel (İsimsiz), 2015, Ayakkabı Fırçaları, Çeşitli Boyutlar.

Biçimsel yaratımın temeli estetik bir bütünlük ve uyumlu bir anlatıma ulaşmaktır. Bu nedenle estetik nesne üretiminde iki boyutlu ve üç boyutlu görsel tasarım öğe ve ilkelerine odaklanılır. Bunlar aynı zamanda eserin biçimsel analizinde de yol göstericidir. Bu tasarım öğelerinin tasarım ilkeleri doğrultusunda kullanılmasıyla bütünsel bir düzene ya da kompozisyona ulaşılır, yani biçim ortaya çıkar. Bu noktada Şakir Gökçebağ'ın duvar ve zemindeki nesneleri yaratıcılık teknik ve stratejilerini içinde barındıran bütünlüklü ve dengeli kompozisyonlar sunmaktadır. Ayrıca geometrik soyut biçimler, kaligrafik öğeler ve jestlerle birlikte süs (ornamentalizm) sanatçı tarafından kullanılan elemanlardandır. "Batı görsel sanat tarihinde uzun süre görmezden gelinen ve dekoratif sanatların önemli bir tasarım ilkesi olarak ihmal edildikten sonra, süsleme, çağdaş sanatta temsil ve soyutlama arasında estetik bir özne olarak düşünülen ve ele alınan önemli bir tema haline gelmiştir" (Schönfelder, 2017:15). Çalışmalarındaki Doğu-Batı bireşimi ya da zıtlığı süsleme unsurunda da ortaya çıkar. Doğu kültürünün hem dekoratif amaçlı unsurlarından biri olan hem de kendi içinde sahip olduğu motif ve renk birliği ile halı, sanatçının çalışmalarında Batı'nın form diliyle birleştirilir. Örneğin 
"Stop and Go (Dur ve Git)/2017" isimli eserinde uzun ebatlara sahip bir halı her biri doksan derece döndürülerek kesilmiş olarak duvarda sergilenmiştir (Görsel 13). Böyle bir müdahale ile teknik nesnedeki bütünlüklü süsleme öğeleri yer değiştirmiştir. Bütüne bakıldığında beş eşit kare parça olarak düzenlenmiş nesne yeni bir ritmik dil yaratmıştır. "Ohne Titel (İsimsiz) / 2016" adlı, duvar yüzeyinde pencere parmaklığı gibi algılanan ve kaligrafik bir etki bırakan kesilmiş şemsiye sapları ile düzenlediği diğer bir çalışmada da dekoratif süs öğesi yine hissedilmektedir (Görsel 14).

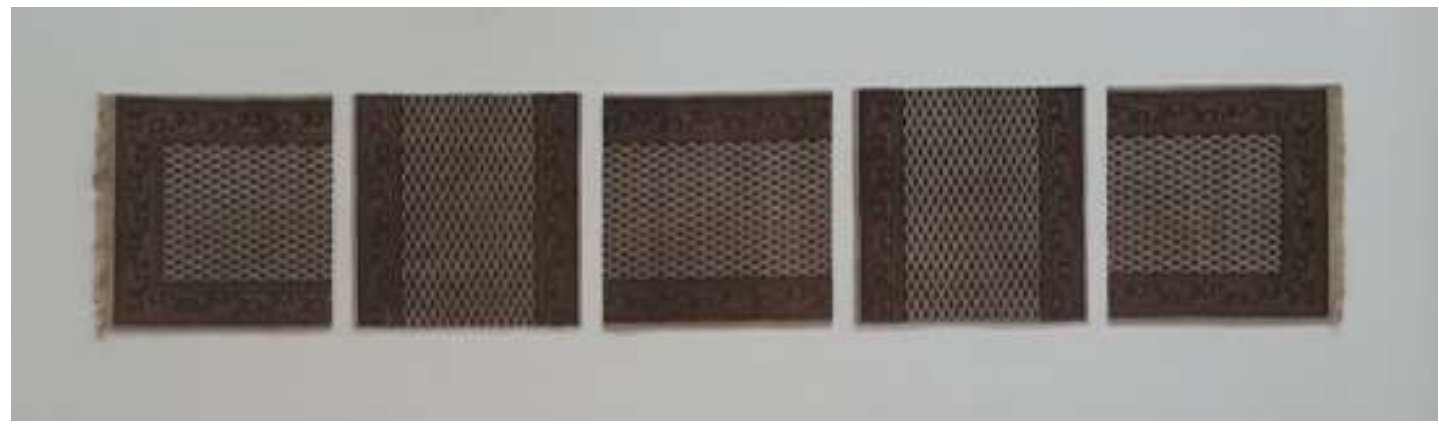

Görsel 13. Şakir Gökçebağ, Stop and Go (Dur ve Git), 2017, Yolluk, 82x444 cm.

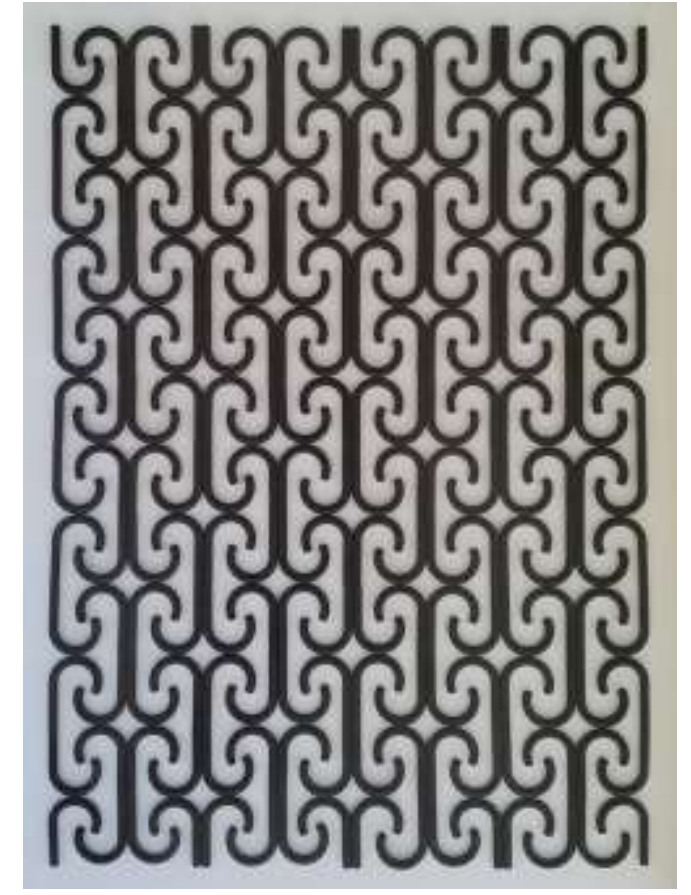

Görsel 14. Şakir Gökçebağ, Ohne Titel (Isimsiz), 2016, Şemsiye Sapları, 185×130x2 cm. 
SDÜ ART-E

Güzel Sanatlar Fakültesi Sanat Dergisi

Aralık'19 Cilt:12 Sayı:24

ISSN 1308-2698

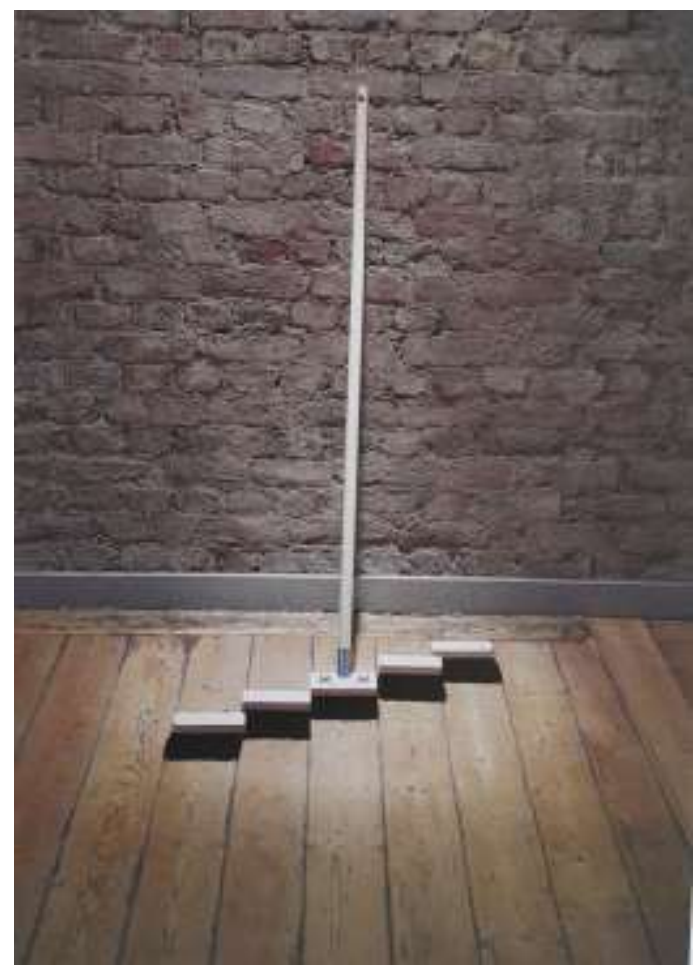

Görsel 15. Şakir Gökçebağ, $F R C$, 2007, Süpürge, 140x80x75cm.

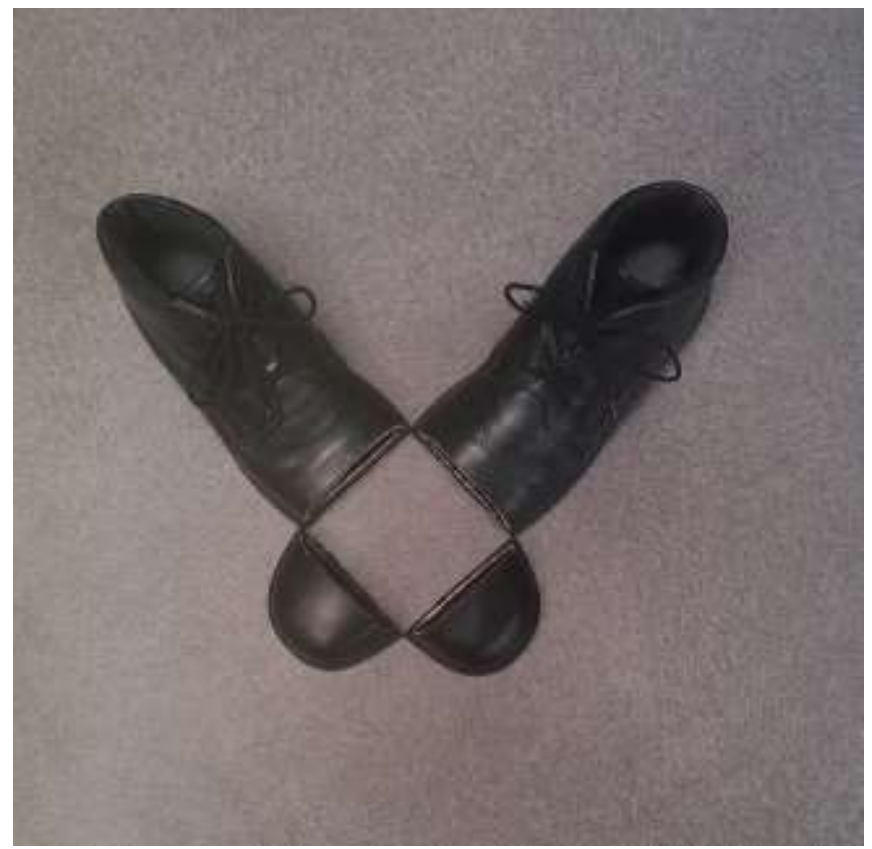

Görsel 16. Şakir Gökçebağ, Open Square I (Açık Kare I), 2007, Bir Çift Ayakkabı. 
Günlük yaşamda alışımış kullanım alanlarına sahip olan seri üretim nesneler sanatta malzeme olarak kullanıldığında farklı anlam katmanları kazanır. Gökçebağ’ın bu eşyaları kullanma şekli onları kendi dar ortamlarından özgürleştirerek yeni, şaşırtıcı görünümlerin ortaya çıkmasına izin verir (Schönfelder, 2017:13). Sanatçı çoğunlukla teknik nesnenin biçimine müdahale ederek kullanır ama elbette yapıbozuma uğratmadığı nesneleri de vardır. Son çözümlemede işleri çoğaltma, tekrar ve katmanlama yoluyla tekilden tümele doğru evrilir. Birimden bütüne giden yolda nesneler mekânın aurasına eklemlenir. Bunların tümünde sanatçının titiz ve kontrollü yaklaşımı hep belirgindir. Elle üretmek yerine bir insan bilmesinin sonucu olan teknik nesneyi tercih etmekte, ironi temelli işlerinde sıradanlık ve basitliği seçmektedir. Ayrıca Doğu ile Batı́nın birleştirici ya da farklı unsurlarını birbiriyle çakıştırmasına bakarak da Gökçebağ'ın sanatında sanat tarihinden ve kişisel referanslardan beslendiği görülmektedir.

\section{Sonuç}

Şakir Gökçebağ’ın malzeme olarak teknik nesne kullandığı üretimleri arasında teknik nesnenin biçimine müdahale ettikleri ve etmedikleri şeklinde genel bir sınıflandırma yapılabilir. Seçtiği nesneye biçimsel anlamda müdahalesi oldukça naiftir, çoğunlukla yalnızca kesme eylemiyle sağlar bunu. Yine de müdahalede bulunduğu nesnenin ne olduğu, kimliği anlaşılır durumdadır. Nesne tam anlamıyla tanınırlığını kaybetmemiştir. Aslında Gökçebağ’ın bu müdahaleleri nesnenin işlevini değiştirecek şekildedir daha çok. Sanatçının bu yönlü bir tercihi daha ön planda gözükmektedir. Kesilmiş bir kemer, halı, ayakkabı, plastik hortum ya da kovanın sanatçının müdahalesinden sonra tanınması mümkün görünmektedir. Fakat ne oldukları anlaşılan bu nesneler veya bütünden ayrılan parçalar eski işlevlerine bir daha asla sahip olamayacaklardır. Sanatçı mümkün olduğunca az müdahale ile teknik nesnenin yapısını geri döndürülemeyecek şekilde bozmaktadır.

Teknik nesne amacı dışında bir alana, bir sanatçı tercihiyle sanat alanına taşındığında gerçek kimliği soyutlanarak sanat nesnesi kimliğini kazanmaktadır. Ancak hazır nesne tekniği ile sanat alanına taşınan teknik nesne sanatsal kimliğini ve işlevsel kullanım nesnesi olma durumunu sonsuza kadar korumaktadır. Artık nesnenin eski ve yeni kimliği bir aradadır, üst üste binmiştir. Bu nedenle çift kimlikli olan hazır nesne önceki bağlamına yeniden döndüğünde sanat 
eseri kimliğini de hep hatırlatacaktır, ya da bu ona bakanların zihninde belirecektir. Transpozisyon ile dönüştürülen ve çift kimliği yapısında taşıyan bir hazır nesne tekrar, ikinci kez bir hazır nesne olarak sunulamaz. Yani hazır nesne olarak sunulan teknik bir nesne de tekleşir (unique). Gökçebağ’ın ise tekrar, seri ve çoğaltma eğilimiyle aynı teknik nesneyi kullandığı farklı işleri mevcuttur. Çalışmaları deneysel, çeşitlemeli ve süslemeci jestler taşımaktadır. Biçimine müdahale etmediği nesnelerde bile beğeni ve hoşa gitme gibi duygulara neden olacak bazı estetik kural ve düzenlemeler göstermektedir. Zaten sanatçının kendisinin de belirttiği gibi nesne ve mekâna göre uzun araştırmalar, düşünmeler ve planlamalar sonucu üretilirler. Buradan bakışla da Gökçebağ’ın işleri hazır nesne mantığından uzaklaşmaktadır.

Şakir Gökçebağ'ın teknik nesneleri bağlam değiştirip işlevsizleştirilmiş ya da biçimine müdahale edilmemiş dahi olsalar hazır nesne statüsünü kazanamazlar. Zira sanatçının estetik nesneleri görsel tasarım ilkelerine göre düzenlenmişlerdir, yani sanatçı üretimlerinde estetik kaygı gütmektedir. Gökçebağ’ın estetik nesneye dönüşen teknik nesneleri hazır nesne olarak adlandırılacaklarsa eğer bir daha asla ilk kimliklerine dönemeyecekleri göz önünde bulundurulmalıdır. Çünkü artık tam anlamıyla ne bir halı, ne bir şemsiye ne de bir ayakkabıdırlar. Dolayısıyla transpozisyon ile sanat nesnesine dönüşmedikleri için hazır nesne olamazlar. Hazır nesne yanlış bir tabirle sanatta malzeme olarak kullanılan teknik nesnenin bir adı değil bir sonucun, bir statünün adıdır. Sonuç olarak çağdaş Nesne Sanatı́nda önemli bir isim olan Şakir Gökçebağ teknik nesneyi metamorfoz ile estetik nesneye dönüştürmektedir.

\section{Kaynakça}

Altuğ, T. (2012). Son Bakışta Sanat, 1. Baskı, İstanbul: Yapı Kredi Kültür Sanat Yayıncılık.

Auer, B. (2017). "Reorientation", Şakir Gökçebağ Minifesto içinde, ed. Şakir Gökçebağ, Germany: Distanz, s.5-9.

Baudrillard, J. (2005). Şeytana Satılan Ruh ya da Kötülüğün Egemenliği, çev. Oğuz Adanır, Birinci Basım, İstanbul: Doğu Batı Yayınları.

Glasmeier, M. (2013). "In The Minds of Things", Şakir Gökçebağ Prefix \& Suffix içinde, ed. Barbara Heinrich, Kassel: Thiele \& Schwarz, s.4-14.

Graf, M. (2011). "Şakir Gökçebağ", Her Yerde Evinde içinde, ed. Mine Haydaroğlu, İstanbul: Yapı Kredi Yayınları, s.24-39. 
SDÜ ART-E

Güzel Sanatlar Fakültesi Sanat Dergisi

Aralık'19 Cilt:12 Sayı:24

ISSN 1308-2698

Merleau-Ponty, M. (2005). Algılanan Dünya, çev. Ömer Aygün, Birinci Basım, İstanbul: Metis Yayınları.

Özayten, N. (1997). "Yerleştirme", Eczacıbaşı Sanat Ansiklopedisi, İstanbul: YEM Yayın, Cilt 3, s.1939-1940.

Schönfelder, B. (2017). "Brella \& Et Cetera /Brella @ Cetera”, Şakir Gökçebağ Minifesto içinde, ed. Şakir Gökçebağ, Germany: Dıstanz, s.13-17.

\section{İnternet Kaynakları}

Metin, M. (2015), "Şakir Gökçebağ’ın Evrensel Objeleri", Think Thank, Galerist, http://www.galerist.com.tr/wp-content/uploads/downloads/2015/03/SAKIR_GOKCEBAG5.pdf Erişim tarihi: 03.04.2019.

"'Önüm Arkam Sağım Solum', Şakir Gökçebağ", ADAS, (11 Eylül-21Ekim 2017)", http://kolajart.com/wp/2017/09/08/onum-arkam-sagim-solum-sakir-gokcebag-adas-11-eylul21ekim-2017/, Erişim tarihi: 26.02.2019.

"Şakir Gökçebağ Portfolyo Serisi 1" http://platosanat.org.tr/Uploads/Document/c6575d4ee019-4123-a96c-6f0c68a991e5.pdf?v-636421616092235780, Erişim tarihi: 26.02.2019.

"Şakir Gökçebağ 'Think Thank'”, http://www.galerist.com.tr/wp-content/uploads/downloads/ 2015/02/SAKIR-GOCEBAG_THINK-TANK_BB2.pdf, Erişim tarihi: 03.04.2019.

Topal, D. (2017). “Her Şey 'Neden Olmasın?' ile Başlar 'Şakir Gökçebă̆'”, İstandist, https://istandist.com/her-sey-olmasin-ile-baslar-sakir-gokcebag/, Erişim tarihi: 20.06.2019.

\section{Görsel Kaynaklar}

Görsel 1. Marcel Duchamp, Bicycle Wheel (Bisiklet Tekeri), 1913/1951, Hazır Nesne, MOMA, New York, https://www.moma.org/learn/moma_learning/marcel-duchamp-bicycle-wheel-newyork-1951-third-version-after-lost-original-of-1913/, Erişim tarihi: 23.07.2019.

Görsel 2. Şakir Gökçebağ, Minifesto, 2016, Plastik Kovalar, 165 x 128 x 5 cm., ŞAKIR GÖKÇEBAĞ Minifesto, ed. Şakir Gökçebağ, Germany: Distanz, s.54.

Görsel 3. Marcel Duchamp, Comb (Tarak), 1916, Hazır Nesne, Philadelphia Museum of Art, Louise ve Walter Arensberg Koleksiyonu, https://www. toutfait.com/unmaking_the_museum/ Comb.html, Erişim tarihi: 23.07.2019.

Görsel 4. Şakir Gökçebağ, Ohne Titel (İsimsiz), 2017, Plastik Kovalar, 26x180x165cm., Şakir Gökçebağ Minifesto, ed. Şakir Gökçebağ, Germany: Distanz, s.158. 
Görsel 5. Şakir Gökçebağ, Skyscraper \# 3 (Gökdelen \# 3), 2011, Şerit Metreler, Çeşitli Boyutlar, Şakir Gökçebağ Prefix \& Suffix, ed. Barbara Heinrich, Kassel: Thiele \& Schwarz, s.35.

Görsel 6. Şakir Gökçebağ, Three Basic Prayers (Üç Temel Dua), 2010, 102x42x1cm., Graf, M. (2011). "Şakir Gökçebağ", Her Yerde Evinde, ed. Mine Haydaroğlu, İstanbul: Yapı Kredi Yayınları, s.35.

Görsel 7. Şakir Gökçebağ, KV1 18, 2016, Plastik Kovalar, 27x117x117 cm., Şakir Gökçebağ Minifesto, ed. Şakir Gökçebağ, Germany: Distanz, s.85.

Görsel 8. Şakir Gökçebağ, Ohne Titel (İsimsiz), 2008, Ütü, Çeşitli Boyutlar, Şakir Gökçebağ Prefix \& Suffix, ed. Barbara Heinrich, Kassel: Thiele \& Schwarz, s.133.

Görsel 9. Şakir Gökçebağ, Ohne Titel (İsimsiz), 2011, Şemsiye, 46x48x6 cm., Şakir Gökçebağ Prefix \& Suffix, ed. Barbara Heinrich, Kassel: Thiele \& Schwarz, s.60.

Görsel 10. Şakir Gökçebağ, TRK-4, 2011, Tarak, 60 x 80 cm., "Combosition" Serisinden, Şakir Gökçebağ Minifesto, ed. Şakir Gökçebağ, Germany: Distanz, s.140.

Görsel 11. Şakir Gökçebağ, Ohne Titel (İsimsiz), 2017, Oluklu Levha, Ø 205 cm., Şakir Gökçebağ Minifesto, ed. Şakir Gökçebağ, Germany: Distanz, s.93.

Görsel 12. Şakir Gökçebağ, Ohne Titel (İsimsiz). 2015, Ayakkabı Fırçaları, Çeşitli Boyutlar, Şakir Gökçebağ Minifesto, ed. Şakir Gökçebağ, Germany: Distanz, s.52.

Görsel 13. Şakir Gökçebağ, Stop and Go (Dur ve Git), 2017, Yolluk, 82x444cm., Şakir Gökçebağ Minifesto, ed. Şakir Gökçebağ, Germany: Distanz, s.100.

Görsel 14. Şakir Gökçebağ, Ohne Titel (İsimsiz), 2016, Şemsiye Sapları, 185 x 130x2 cm., Şakir Gökçebağ Minifesto, ed. Şakir Gökçebağ, Germany: Distanz, s.45.

Görsel 15. Şakir Gökçebağ, FRC, 2007, Süpürge, 140 x 80 x 75 cm., Şakir Gökçebağ Prefix \& Suffix, ed. Barbara Heinrich, Kassel: Thiele \& Schwarz, s.132.

Görsel 16. Şakir Gökçebağ, Open Square I (Açık Kare I), 2007, Bir Çift Ayakkabı, Şakir Gökçebağ Minifesto, ed. Şakir Gökçebağ, Germany: Distanz, s.81. 